\title{
Impact study of hygiene and health counseling as a controlling measure of iron deficiency Anemia
}

\author{
Saha J. ${ }^{1}$, Mazumder S. $(\text { Sen })^{2}$, Samanta A. ${ }^{3}$ \\ ${ }^{1}$ Jayanta Saha, Research Scholar in Physiology, ${ }^{2}$ Dr. Sahana Mazumder (Sen), Associate Professor, Department of \\ Physiology, Rammohan College (P.G. Studies), University of Calcutta, ${ }^{3}$ Dr. Amalendu Samanta, Ex. ARO Physiologist, \\ All Indian Inst. of Hygiene \& Public Health Calcutta, West Bengal, India.
}

Corresponding Author: Jayanta Saha, E-mail: jsaha4130@gmail.com

\begin{abstract}
Background and Aim: Anemia is a moderate to severe public health problem in India. Coverage of anemia programmes are inadequate, safe water and sanitation status is moderate or poor, open defecation rates are significant, incidence of diarrhoeal diseases are high as a results of infection. Though poor bio-availability of iron is the root cause of iron deficiency anemia (IDA) the role parasites infection such as hookworm infection also plays a major role in IDA. There is a link between poor hygiene practices -worm infection- IDA. Hence this study was undertaken to educate women of reproductive age group (WRA) about impact of IDA and how good hygiene practice can eliminate the problem to at least some extent. Methods and Material: Women of reproductive age group (WRA) in rural population were taken randomly for this study. They was first screened for anemia and then IDA. The ID anemic women were then randomly allocated into two groups one as experimental and another as control. Base line hematological parameters and hygiene practices were obtained from them. Only the experimental group was counselled about good hygiene practices. The final hematological parameters and hygiene practices were obtained after eighteen months and were compared for statistical significance. Results: At the end of the study 306 women were found to be non anaemic in experimental group while in control group it was only 78 women. Statistical significant results were obtained in hygiene practices between experimental and control group. Conclusion: Our study hence shows that good hygiene practice does play an important role in controlling anemia.
\end{abstract}

Keywords: Anemia, Defecation, Hand washing

\section{Introduction}

Anemia is a disorder of the blood in which a person does not have enough hemoglobin, the protein responsible for carrying oxygen throughout the body.

Globally, two billion people are anaemic, which includes 315 million (95\% CI: 291-340) in the SouthEast Asia Region (SEAR)[1]. Iron deficiency, the primary contributor to anemia, is the most widespread nutritional disorder while other micronutrient deficiencies including folate and vitamin B12 also contribute to anemia. Recent evidence indicates a greater role for anemia of inflammation caused by parasitic infections including malaria [2]. Iron deficiency anemia (IDA) is a significant public health problem in India. The National Family Health Survey (NFHS -2)[3], India reported that anemia is a major

\footnotetext{
Manuscript received: $27^{\text {th }}$ December 2017

Reviewed: $4^{\text {th }}$ January 2018

Author Corrected: $12^{\text {th }}$ January 2018

Accepted for Publication: $17^{\text {th }}$ January 2018
}

health problem with over half of the women of reproductive age (WRA, 15-49 years) years having the condition. It was reported that 53.9 percent among women in the age group of 15-49 years living in rural area and 45.7 percent of urban women any form of anemia[3]. In the report of data in NFHS-3 it revealed that among married women between the ages of 15-49 years, the prevalence of anemia has risen from 51.8 percent in 1998-99 (NFHS-2) to 56.1 percent in 200506 (NFHS-3)[4]. In Chhattisgarh state as per NFHS3 data the percentage of rural women having any form of anemia is $59.4 \%[5]$. Thus, it is obvious that this problem clearly requires immediate attention and intervention. There are many causes of low hemoglobin, which involve too little production or too much destruction of hemoglobin. On the production side, Nutritional deficiencies, mainly of iron, caused by inadequate diet is the predominant cause of anemia in the south east Asia region (SEAR) [6]. 


\section{Original Research Article}

However, low hemoglobin can also be caused by lack ofvitamin B12 and folic acid, two nutrients necessary for the production of red blood cells. Hence it may be stated that although the primary cause of anemia is irondeficiency, it is seldom present in isolation. More frequently it coexists with a number of other causes, such as malaria, parasitic infection, and haemoglobinopathies.

Parasites are well known to cause of anemia. Intestinal parasites causeanemiabycausing blood loss in the stool, lack of appetite, increased motility of food through the intestine, competition for nutrients, and damage to the intestinal wall that lead stodecreasedabsorption of nutrients, includingiron, vitamin B12and folicacid [7-9].

Open defecation, the practice of defecating outside without a toilet or latrine, may be an important cause of hemoglobin deficiency around the world, and particularly in South Asia. Among the world's regions, sub-Saharan Africa and South Asia continue to have the lowest sanitation coverage [10].

In addition to that hygiene practices like use of slippers during defecation regular trimming of one's nails, washing of hands before eating, washing of hand with soap after defecation or when contacted with excreta are all properhygiene practices failing of which lead to faecal-oral route of transmission of pathogens leading to environmental enteropathy, which may permanently damage the intestine leading to poor absorption of micronutrients. In a recent systematic review of 42 studies of observed handwashing with soap in 19 countries, it was estimated that only $19 \%$ of people worldwide wash their hands after potential contact with excreta [11].

Consequences of haemoglobin deficiencyHemoglobin deficiency has beenshown to have many negative consequences. In adults, it reduces work capacity and thusproductivity, and is a major cause of maternal mortality in developing countries [12-14]. Children who are hemoglobin deficient haveimpaired cognitive ability and physical development, and are more susceptible to disease [15-17].

Past efforts in IDA control and present aim of this study:Major approaches in battling IDA previously were medicinal supplementation with iron and folic acid although supplementation with iron is considered necessary for groups at high risk asa short-term emergency measure, it fails to address the root causes and cannot provide the overall long-term benefits of economy and sustainability. Evaluation studies of India's nationwide and long-standing supplementation programme showed irregular supplies, non-compliance by the beneficiaries, poor counselling, etc. As such, the supplementation strategy has proved to be inadequate [18].

As per existing knowledge, there have been no randomized controlled trials of the effect of latrine or toilet provision on hemoglobin status especially in rural population especially in the state of Chhattisgarh This study was hence undertaken with a view that such a trial would make an important contribution to the literature on the determinants of anemiaamong rural population where open defecation is rampant and other hygiene practices are poorly followed.

\section{Methods and Materials}

This is a longitudinal interventional study done on rural women of reproductive age (WRA) group of 14-49 years.

Place of field study: District Mungeli of state Chhattisgarh.

Period of the study: January 2014 to September 2016 With due discussion with program officers of women and child development office of the district and block medical officer, five villages of was chosen for this study where anemia prevalence were suspected to be more common among women, and those place which are not endemic to malaria. With due consent of women who volunteer for the study, screening test was first done to find out the women suffering from anemia and then those found to be anemic were screened for iron deficiency anemia(IDA).

The CDC/WHO expert groups on 7th May 2004 recommended that hemoglobin and serum ferritin are the most valuable indicators of the impact program to control iron deficiency [19].

Exclusion criteria-Those women who informed that they were suffering from any diseases and which was suspected to be of inflammatory type and those suffering from any hemoglobinopathies were excluded from the study.

Also women informing having recent major surgery or hemorrhagic incident were excluded.

Inclusion criteria- Apparently health women of age between 14-49 years, non-pregnant and non-lactating women were taken for the study. 


\section{Original Research Article}

A total of 2105 women of age group were screened for haemoglobin out of which $76 \%$ that is 1600 were found to be anaemic. Women who were found to be anaemic were then tested for ferritin test out of which $73 \%$ that is 1168 women were found to be suffering from IDA.

IDA was considered when haemoglobin values falls below $12.0 \mathrm{gm} / \mathrm{dl}$ of blood and ferritin value less than $15.0 \mathrm{ng} / \mathrm{ml}$ of blood [20].

At the baseline 584 IDA women from 305 household were included in the experimental group and 584 women from 310 household were included in control group by purposive random sampling.

In this study, anemia was defined according to the World Health Organization (WHO) definition as a baseline hemoglobin concentration less than $12.0 \mathrm{mg} / \mathrm{dl}$ [21].

Base line study include estimation of haemoglobin, ferritin, Total Iron Binding capacity (TIBC) estimation of women and evaluation of hygiene practices viz. use of latrine for defecation, use of slippers during defecation,trimming of nails, washing of hands before eating and washing of hands after defecation or when in contact with excreta Of both experimental and control group by interview schedule.

Haemoglobin was estimated by cynameth- hemoglobinmethod and serum ferritin by radioimmuassay (RIA). Serumtotal iron binding capacity (TIBC) was estimated by estimated by iron and TIBC kit in semiautoanalyzer, by Ferrozine method [22-23].

Our main focus was to give counselling to women in experimental group to inculcate good hygiene practices to prevent transmission of worms either by foot or by faecal-oral route. Counselling includes basic health concepts about IDA as public health problems. To educated them about sources of parasitise infection and how it leads to IDA, faecal-oral route of parasite infection transmission and how better hygiene practices can be adopted for preventionof the same.

Hygiene practice that were counselled to them were use of latrine for defecation, use of slippers during defecation, trimming of nails, washing of hands before eating and washing of hands with soap after defecation or when in contact with excretaand what are their benefit in practicing in prevention of anemia. Easily available and economical tools were suggested to them so that the counselling does not become burdensome and unacceptable to them. Interactions with the women were done in local language in very simple communicable way. Posters regarding hygiene practices were used for better understanding and for the illiterate.

Though the experimental group receives counselling the control group was reframed from such counselling from the investigator.

After baseline study the haematological and hygiene predictors thus latrine use for defecation, use of slippers during defecation were again carried out after six months for both groups (other hygiene predictors at the end of the study) and those women still found to be anaemic in experimental group was re-counselled.

The procedure was repeated again at twelve months and finally at the 18th month's data of both experimental and control group were statistically analysed to study the impact of hygiene and health counselling as a controlling measure of anemia

Blood sample collection- Blood samples were taken to perform haemoglobin to determine serum concentrations of ferritin and TIBC. Each sample consisted in $5 \mathrm{ml}$ of blood taken from the antecubital vein of the arm after cleaning of the zone with isopropyl alcohol. From this, $4 \mathrm{~mL}$ were used to obtain serum and $1 \mathrm{ml}$ was treated with EDTA for haemoglobin. Serum samples were obtained by centrifugation of blood samples, within 4 hours of extraction. Serum was kept at optimum temperature and protected from light until analysis. Necessary ethical approval was taken for this study

Statistical analyses- The Kolmogorov-Smirnov test was used to assess normality of the continuous data. Since our Kolmogorov-Smirnov test results showed that our continuous data viz. heamoglobin $(\mathrm{Hb})$, Ferritin and TIBC were not normally distributed we opted for nonparametric tests [24].

Man-Whitney test was conducted to compare the median and mean ranks of haematological indicators viz. heamoglobin $(\mathrm{Hb})$, Ferritin and TIBC.

Chi-square test was performed for categorical variables.Binary logistic regression was run to assess the impact of the hygiene predictors on anaemic status.

All statistical tests were 2-tailed and differences were considered significant at $\mathrm{p}<0.05$. Statistical analysis was done by SSPS version 22[25]. 


\section{Results}

Socio-Demographic profile of women- Mean age of women in experimental group is 25 years \pm 7.6 and ranging from 14 years to 45 years and for control group the mean age is 24 yrs \pm 7.8 years and ranging from 14 years to $45 \mathrm{yrs}$.

As per religion all women were predominately Hindu. Nearly all the subjects were from families engaged in agriculture or agriculture labour.

At the end of the study that is after 18 th months 10 women opted out of the study in experimental group and 8 women opted out from the control group.

To keep the sample size equal we kept sample size of both group at 574 .

From table I it was observed that in terms of defecation in the experimental group $(n=374) 65.2 \%$ women opted for latrine uses from $(n=152) 26.5 \%$ baseline value, while in control group only $(n=207) 36 \%$ of the women opted for latrine use from baseline value of $(n=166) 28.9 \%$

Table-I: Personal hygiene indicator in among Women

\begin{tabular}{|c|c|c|c|c|c|c|c|c|c|c|}
\hline $\begin{array}{c}\text { Personal } \\
\text { Hygiene } \\
\text { Indicators }\end{array}$ & \multicolumn{2}{|c|}{ Base line } & \multicolumn{2}{|c|}{$\begin{array}{r}\text { After Six } \\
\text { months }\end{array}$} & \multicolumn{2}{|c|}{$\begin{array}{c}\text { After Twelve } \\
\text { Months }\end{array}$} & \multicolumn{2}{|c|}{$\begin{array}{c}\text { After eighteen } \\
\text { months }\end{array}$} & \multirow[t]{2}{*}{$\begin{array}{c}\mathbf{P} \\
\text { Value }\end{array}$} & \multirow[t]{2}{*}{$\mathrm{X}^{2}$ Value } \\
\hline $\begin{array}{l}\text { In terms of } \\
\text { Frequency } \\
\text { \& Percentage }\end{array}$ & Exp. & Control & Exp. & Control & Exp. & Control & Exp. & Control & & \\
\hline $\begin{array}{c}\text { Sanitary Latrine } \\
\text { use }\end{array}$ & & & & & & & & & & \\
\hline Frequency & 152 & 166 & 160 & 166 & 298 & 174 & 374 & 207 & $<0.000$ & 97.18 \\
\hline percentage & 26.5 & 28.9 & 27.9 & 28.9 & 51.9 & 30.3 & 65.2 & 36.1 & 5 & \\
\hline $\begin{array}{c}\text { No use } \\
\text { Of latrine }\end{array}$ & & & & & & & & & & \\
\hline Frequency & 422 & 408 & 414 & 408 & 276 & 400 & 200 & 367 & & \\
\hline percentage & 73.3 & 71.1 & 72.1 & 71.1 & 48.1 & 69.7 & 34.8 & 63.9 & & \\
\hline $\begin{array}{l}\text { Slipper use } \\
\text { Frequency }\end{array}$ & 85 & 77 & 124 & 83 & 216 & 86 & 401 & 89 & & \\
\hline percentage & 14.8 & 13.4 & 21.6 & 14.5 & 37.6 & 15.0 & 69.9 & 15.5 & $\begin{array}{c}<0.000 \\
5\end{array}$ & 346.6 \\
\hline $\begin{array}{l}\text { Nouse of } \\
\text { slipper }\end{array}$ & 489 & 497 & 450 & 491 & 358 & 488 & 173 & 485 & & \\
\hline $\begin{array}{l}\text { Frequency } \\
\text { percentage }\end{array}$ & 85.2 & 86.6 & 78.4 & 85.5 & 62.4 & 85.08 & 30.1 & 84.5 & & \\
\hline
\end{tabular}

Both experimental and control group contained equal no of anaemic women $(n=574)$

Regarding use of slippers during defecation it has been observed that after 18th months in the experimental group $(n=401) 69.9 \%$ women were using slipper from baseline value of $(n=85) 14.8 \%$ whereas it is only $(n=89) 15.5 \%$ in control group from baseline value of $(n=85) 14.8 \%$.

As personal hygiene is concern in terms of regular trimming of nails it was found from table IIthat in experimental group there is increase from $(n=259) 45.1 \%$ in baseline to $(n=374) 65.2 \%$ at the end of the study and in control group in baseline it was $(n=274) 47.7 \%$ and $(n=283) 49.3 \%$ at the end of study. 
Original Research Article

Table- II: Personal hygiene indicator in among Women.

\begin{tabular}{|c|c|c|c|c|c|c|c|}
\hline \multirow{2}{*}{$\begin{array}{c}\text { Personal } \\
\text { Hygiene } \\
\text { Indicators }\end{array}$} & & \multicolumn{2}{|c|}{ Baseline } & \multicolumn{2}{|c|}{ After Eighteen months } & \multirow[t]{2}{*}{ P Value } & \multirow{2}{*}{$\begin{array}{c}\mathrm{X}^{2} \\
\text { Value }\end{array}$} \\
\hline & & Experimental & Control & Experimental & Control & & \\
\hline $\begin{array}{c}\text { Regular } \\
\text { Trimming } \\
\text { of nails }\end{array}$ & $\begin{array}{l}\text { Frequency } \\
\text { Percentages }\end{array}$ & $\begin{array}{l}259 \\
45.1\end{array}$ & $\begin{array}{l}274 \\
47.7\end{array}$ & $\begin{array}{l}374 \\
65.2\end{array}$ & $\begin{array}{l}283 \\
49.3\end{array}$ & \multirow[t]{2}{*}{$\mathrm{P}<0.0005$} & \multirow{2}{*}{29.47} \\
\hline $\begin{array}{c}\text { No Regular } \\
\text { Trimming } \\
\text { of nails }\end{array}$ & $\begin{array}{l}\text { Frequency } \\
\text { Percentages }\end{array}$ & $\begin{array}{l}315 \\
54.9\end{array}$ & $\begin{array}{l}300 \\
52.3\end{array}$ & $\begin{array}{l}200 \\
34.8\end{array}$ & $\begin{array}{l}291 \\
50.7\end{array}$ & & \\
\hline $\begin{array}{c}\text { Washing of } \\
\text { hand before } \\
\text { eating }\end{array}$ & $\begin{array}{l}\text { Frequency } \\
\text { Percentages }\end{array}$ & $\begin{array}{l}179 \\
31.2\end{array}$ & $\begin{array}{l}214 \\
37.3\end{array}$ & $\begin{array}{l}480 \\
83.6\end{array}$ & $\begin{array}{l}239 \\
41.6\end{array}$ & \multirow[t]{2}{*}{$\mathrm{P}<0.0005$} & \multirow[t]{2}{*}{216.16} \\
\hline $\begin{array}{c}\text { Non } \\
\text { Washing of } \\
\text { hand before } \\
\text { eating }\end{array}$ & $\begin{array}{l}\text { Frequency } \\
\text { Percentages }\end{array}$ & $\begin{array}{l}395 \\
68.8\end{array}$ & $\begin{array}{l}360 \\
62.7\end{array}$ & $\begin{array}{c}94 \\
16.4\end{array}$ & $\begin{array}{l}335 \\
58.4\end{array}$ & & \\
\hline $\begin{array}{l}\text { Washing of } \\
\text { hand with } \\
\text { soap after } \\
\text { defecation }\end{array}$ & $\begin{array}{l}\text { Frequency } \\
\text { Percentages }\end{array}$ & $\begin{array}{l}129 \\
22.5\end{array}$ & $\begin{array}{l}145 \\
23.5\end{array}$ & $\begin{array}{l}410 \\
71.4\end{array}$ & $\begin{array}{l}154 \\
26.8\end{array}$ & \multirow[t]{2}{*}{$\mathrm{P}<0.0005$} & \multirow[t]{2}{*}{228.41} \\
\hline $\begin{array}{c}\text { Non } \\
\text { Washing of } \\
\text { hand with } \\
\text { soap after } \\
\text { defecation }\end{array}$ & $\begin{array}{l}\text { Frequency } \\
\text { Percentages }\end{array}$ & $\begin{array}{l}445 \\
77.5\end{array}$ & $\begin{array}{l}429 \\
74.7\end{array}$ & $\begin{array}{l}164 \\
28.6\end{array}$ & $\begin{array}{l}420 \\
73.2\end{array}$ & & \\
\hline
\end{tabular}

Both experimental and control group contained equal no of women $(n=574)$

Major changes were observed in experimental group regarding hand washing with soap after defecation or when contact with excreta.

Hand washing with soap after defecation in experimental group increased to $(n=410) 71.4 \%$ after 18th months from baseline value of $(n=129) 22.5 \%$ while in control group there is a marginal rise from $(n=145) 23.5 \%$ to $(n=154) 26.8 \%$.

Hand washing before taking food as observed in experimental group versus control group there is an increase from $(\mathrm{n}=179) 31.2 \%$ to $(\mathrm{n}=480) 83.6 \%$ and $(\mathrm{n}=214) 37.3 \%$ to $(\mathrm{n}=239) 41.6 \%$ respectively.

Statistically significant Chi-square test results $\mathrm{p}<0.005$ were obtained in hygiene predictors viz latrine use,slipper use during defecation, trimming of nails, washing of hand before eating and washing of hands with soap after defecation between experimental and control groups.

A Chi-square test of homogeneity was conducted to test the statistical significance of anemic status after the end of the study among experimental and control groups with an adequate sample size established according to Cochran (1954) [26].

The observed frequencies/count and percentages of anemic status amongexperimental and control groups are presented in the table III along with the $\mathrm{p}$ value and chi- square test value for 18 months.

A statistically significant result was obtained between experimental and control group among different anemic status at 18 months. $\mathrm{X}^{2}(3)=205.23, \mathrm{p}<0.005$. 
Original Research Article

Table- III: Shows the frequency and percentage changes in anaemic status in experimental and control groups in different stages of the study along with the chi-square test results after 18 months.

\begin{tabular}{|c|c|c|c|c|c|c|c|c|c|c|}
\hline & Base & line & & onths & Twel & Months & & $\begin{array}{l}\text { iteen } \\
\text { nths }\end{array}$ & P Value & $\begin{array}{c}X^{2} \\
\text { Value }\end{array}$ \\
\hline $\begin{array}{c}\text { Category of } \\
\text { anemia }\end{array}$ & Exp & Control & Exp & Control & Exp & Control & Exp & Control & \multirow{9}{*}{$\begin{array}{c}\mathrm{P}<0.000 \\
5\end{array}$} & \multirow{9}{*}{205.23} \\
\hline Mild & 295 & 297 & 211 & 210 & 210 & 298 & 178 & 307 & & \\
\hline percentage & 51.4 & 51.7 & 47.2 & 36.6 & 36.6 & 51.9 & 31.0 & 53.5 & & \\
\hline Moderate & 260 & 260 & 291 & 247 & 151 & 221 & 90 & 188 & & \\
\hline percentage & 45.3 & 45.3 & 50.7 & 43.0 & 26.3 & 38.5 & 15.7 & 32.8 & & \\
\hline Severe & 19 & 17 & 11 & 12 & 03 & 04 & 00 & 01 & & \\
\hline \multicolumn{9}{|l|}{ Percentage } & & \\
\hline No Anemia & $\begin{array}{c}\text { All } \\
\text { anaemic }\end{array}$ & $\begin{array}{c}\text { All } \\
\text { Anaemic }\end{array}$ & 82 & 24 & 210 & 51 & 306 & 78 & & \\
\hline Percentage & Nil & Nil & 14.3 & 4.2 & 36 & 8.9 & 53.3 & 13.6 & & \\
\hline
\end{tabular}

Both experimental and control group contained equal no of anaemic women $(n=574)$

Post-hoc analysis involving pair wise comparison using multiple Z- tests of two proportions with a Bonferroni correction was conducted to assess the significance among different anemic status. Statistical significant was accepted at $\mathrm{p}<0.0125$.

There was statistically significant difference in the proportion of experimental group having mild anemia than control group $(n=178,31 \%$ versus $n=307,53 \%)$ as well as the proportion of the experimental group having moderate anemia then control group $(n=90,15.7 \%$ versus $n=188,32.8 \%)$. there were also statistically significant difference in the proportion of experimental group havingno anemia than control group $(n=306,53.3 \%$ versus $n=78,13.6 \%), p<0.0125$. While There were no statistically significant difference in the proportion of experimental group having severe anemia than control group $(\mathrm{n}=0,0.0 \%$ versus $\mathrm{n}=01,0.2 \%) \mathrm{p}>0.0125$.

A Mann-Whitney $U$ test was conducted to determine if there were differences in the median of the haematological indicators viz. haemoglobin, ferritin and TIBC scores in between experimental and control groups. From table IV the Mann-Whitney U test results observed were as follows.

Table- IV: Mann-Whitney test output of hematological indicators after the end of the study (18th months) between experimental and control groups.

\begin{tabular}{|c|c|c|c|c|c|c|c|}
\hline & \multicolumn{2}{|c|}{ Interventional group } & \multicolumn{2}{|c|}{ Control group } & & Mean \\
\hline $\begin{array}{c}\text { Hematological } \\
\text { Indicators }\end{array}$ & Median & $\begin{array}{c}\text { Median } \\
\text { rank }\end{array}$ & $\begin{array}{c}\text { Mean } \\
\text { rank }\end{array}$ & $\begin{array}{c}\text { Mann- } \\
\text { Whitney }\end{array}$ & Z value & P value \\
\hline Hemoglobin(mg/dl) & 12.1 & 748.24 & 11.2 & 400.76 & 65010.5 & -17.78 & $<0.0005$ \\
\hline Ferritin (ng/ml) & 28.0 & 772.27 & 9.5 & 376.73 & 51218.5 & -20.21 & $<0.0005$ \\
\hline TIBC ( $\mu$ g/dl) & 446 & 364.49 & 534 & 784.51 & 44192.5 & -21.63 & $<0.0005$ \\
\hline
\end{tabular}

Both experimental and control group contained equal no of anaemic women $(\mathrm{n}=574) \mathrm{P}<0.0005$

Median $\mathrm{Hb}$ scores (12.1) for experimental and $\mathrm{Hb}$ scores (11.2) for control group was statistically significant in experimental then in control $\mu=65010.5, \mathrm{Z}=-17.78, \mathrm{p}<0.005$

Median ferritin score (28.0), for experimental and ferritin score (9.5) for control group was statistically significant in experimental then in control $\mu=51218.5, Z=-20.21, p<0.005$ 
Median TIBC score (446), for experimental and, TIBC score (534) for control group was statistically significant in experimental then in control $\mu=44192.5, \mathrm{Z}=-21.63, \mathrm{p}<0.005$.

Binary logistic regression test was performed among the experimental group to ascertain the impact of the hygiene predictors on anaemic status. The test results are tabulated in table VI. The logistic regression model was statistically significant $\mathrm{X}^{2}(5)=555.92, \mathrm{p}<0.005$. This model explained $82.9 \%$ (Nagelkerle R2) of the variance in anaemic status. Of the predictors all were statistically significant as shown in table V. Latrine users had 65.81 times mode odds to be non anaemic than those who do open defecation, like wise women wearing slipper during defecation have 88.82 times odds of being non anaemic, Women who regularly trim their nails have 1.671 time odds of being non anaemic, those who wash their hand before eating have times 3.97 times odds of being non anaemic and those women who wash their hands with soap after defecation or when in contact with excretahave 43.25 times odds of being non anaemic then those women who do not.

Table-V: Binary logistic regression of Hygiene predictors predicting anaemic status among women of experimental group at the end of the study.

\begin{tabular}{|c|c|c|c|c|c|c|c|c|}
\hline $\begin{array}{c}\text { Hygiene } \\
\text { Predictors }\end{array}$ & B & SE & Wald & df & P & \multicolumn{2}{|c|}{$\begin{array}{c}\text { Odds } \\
\text { Raito }\end{array}$} & \multicolumn{2}{|c|}{ 95\% CI for Odds } \\
\hline Use of latrine & 4.187 & 0.75 & 29.91 & 1 & $<0.005$ & 65.81 & 14.68 & 295.064 \\
$\begin{array}{c}\text { Use of slippers During } \\
\text { defecation }\end{array}$ & 4.497 & 1.07 & 18.12 & 1 & $<0.005$ & 89.82 & 11.32 & 712.517 \\
$\begin{array}{c}\text { Regular trimming of nails } \\
\text { Washing of hands before } \\
\text { eating }\end{array}$ & 0.513 & 0.177 & 8.45 & 1 & $<0.05$ & 1.571 & 1.182 & 2.362 \\
$\begin{array}{c}\text { Washing of hands with soap } \\
\text { after defecation }\end{array}$ & 3.767 & 0.529 & 49.41 & 1 & $<0.005$ & 43.25 & 15.35 & 121.90 \\
\hline
\end{tabular}

Statistically significant results were obtained for all predictors

\section{Discussion}

Anemia remains to be a problem with multifactorial causes. However, too little progress has been made toward the global elimination of iron deficiency. Part of the reason for this lack of action is the fact that iron deficiency anemia (IDA) has few overt symptoms [27].

From the study results it is evident that personal counselling and educating women regarding their personal hygiene in terms of use of latrine for defecation and wearing slipper during defecation, regular trimming of nails, washing of hands before eating and washing of hands with soap after defecation or when in contact with excreta have a very major impact on reducing cases of anemia as evident from comparing results between experimental group and control group after the end of the study.

Personal hygiene plays a very important role in minimizing worm infection which results in loss of blood consequently leading to iron deficiency anemia.
Our study result shows that intervention in terms of hygiene and health education and counseling among WRA group turned out to be successful in controlling IDA, as evidence from parameters of the hematological testresults. The study results shows that once women become aware about the negative impact of IDA and how good hygiene practices helps in reducing the same they prefer to practice good hygiene practices as evident from the study result. At the end of the study 306 women in the experimental group were non anemic while in control group it turned out to be only 78 women.

The Logistic regression results points out that the hygiene predictors positively and significantly contributes in reducing cases of anemia.

It is important to note that two randomized trials, one from India and one from Indonesia, have found an effect of sanitation programs on child height, and that 


\section{Original Research Article}

the biological mechanisms linking open defecation and height are similar to those proposed to link open defecation and hemoglobin status [28].

For long-term sustainability in prevention of IDA environmental health will be required, improving access to safe water and sanitation and improving hygienic behaviour through health any hygiene education. Since human soil-transmitted helminth (STHs) are faecalborne infections, and transmission occurs either directly (hand-to-mouth) or indirectly (through food and water), reducing faecal contamination of soil can be achieved by promoting the use of latrines, use of slippers during defecation developing self-protection from re-infection, and promoting personal/family hygiene measures such as washing hands before taking food and after defecation or when contact with excreta.

Indeed, Center for Disease Control and Prevention (CDC) has stated: "It is well documented that one of the most important measures for preventing the spread of pathogens is effective hand washing." As a general rule, hand washing protects peoples, best against diseases transmitted through faecal-oral routes [29].

Though sup plantation with iron tablets is a more common practice to counter anemia in moderate to severe cases but it hardly eliminates the root cause. In places with more open defecation, we would expect parasite medicine to be less effective because the chance of re-infection is higher. Sanitation, by contrast, is a public good, which is harder to obtain than medicine or healthy food. It involves fixed costs of construction, as well as maintenance costs. Additionally, parents in poor countries are largely unaware of the negative health impacts of open defecation [30]. Hence awareness through education is more vital.

\section{Conclusion}

Individual hygiene behaviors can be affected by many factors, including beliefs, values, habits, socioeconomic and cultural factors, level of knowledge, personal preferences, family characteristics and physical and social characteristics of the work and living environments. Therefore, the hygiene habits of each individual differ; meaning that these habits are unique to individuals. Hence to achieve a goal to change individual hygiene practices it require first to understand the individual and then to properly counseland educatethem about the negative impact ofnot practicing good hygiene practices like open defecation.
Highlights of our study- It is obvious from this study that personal counselling indeed proves effective in improvement of personal hygiene which ultimately helps in controlling anemia beside past efforts to only control it by way of iron and folic acid supplementation and it is hence highly recommended for the better health of individuals and society.

\section{Funding: Nil, Conflict of interest: None. Permission of IRB: Yes}

\section{References}

1. World Health Organisation. The global prevalence of anemia in 2011.WHO,Geneva, 2015.avilablbe at http:// apps.who.int/iris/bitstream/10665/177094/1/978924156 4960_eng.pdf.Accessed on 15 january 2015

2. Agarwal N, Prchal JT. Anemia of chronic disease (anemia of inflammation). Acta Haematol. 2009; 122 (2-3): 103-8. doi: 10.1159/000243794. Epub 2009 Nov 10.

3. National Family Health Survey (NFHS-2) 1998-99: India: International Institute for Population Sciences. Mumbai. Available at: http://rchiips. org/ NFHS/ data/ india/ indch 7. pdf. Accessed on $10^{\text {th }}$ November 2013.

4. International Institute for Population Sciences (IIPS) and Macro International. 2007. National Family Health Survey (NFHS-3), 2005-06: India: Volume I. Mumbai: Available at rchiips.org/nfhs/NFHS-3\%20Data/VOL-1/ India_volume_I_corrected_17oct08.pdf. Accessed on $10^{\text {th }}$ November 2013

5. National Family Health Survey (NFHS-2) 1998-99: India: International Institute for Population Sciences. Mumbai. Available at http://rchiips.org/NFHS/data/ch/ chfctsum.pdf . Accessed on $10^{\text {th }}$ November 2013

6. World Health Organisation. Safer Water, Better Health: Costs, Benefits, and Sustainability of Interventions to Protect and Promote Health. WHO, Geneva, 2008. Available at http:// apps. who.int/iris/ bitstream/ 10665/ 43840/1/ 9789241596435_eng.pdf. Accessed on 15 January 2015

7. Ngure FM, Reid BM, Humphrey JH, Mbuya MN, Pelto G, Stoltzfus RJ. Water, sanitation, and hygiene (WASH), environmental enteropathy, nutrition, and earlychild development: making the links. Ann N Y Acad Sci. 2014 Jan;1308:118-28. doi: 10.1111/nyas. 12330. 


\section{Original Research Article}

8. Stevens GA, Finucane MM, De-Regil LM, Paciorek CJ, Flaxman SR, Branca F, Peña-Rosas JP, Bhutta ZA, Ezzati M; Nutrition Impact Model Study Group (Anaemia). Global, regional, and national trends in haemoglobin concentration and prevalence of total and severe anaemia in children and pregnant and nonpregnant women for 1995-2011: a systematic analysis of population-representative data. Lancet Glob Health. 2013 Jul;1(1):e16-25. doi: 10.1016/S2214-109X(13) 70001-9. Epub 2013 Jun 25.

9. Rosenberg, I. and B. Bowman. Intestinal physiology and parasitic diseases. Re-views of Infectious Diseases. 1982; 4 (4), 763-767. https://doi. org/10. 1093/ 4. 4.763

10. WHO/UNICEF. Water, sanitation and hygiene in health care facilities: status in low- and middle-income countries and way forward. Geneva: 2015; World Health Organization available at http://who.int/ water_ sanitation_health/publications/wash-health-care-

facilities/en.Accessed on $10^{\text {th }}$ November 2016.

11. Freeman MC, Stocks ME, Cumming O, Jeandron A, Higgins JP, Wolf $\mathrm{H}$ et al. Hygiene and health: systematic review of handwashing practices worldwide and update of health effects. Trop Med Int Health. 2014; 19 (8): 906-16. DOI: $10 . \quad 1111 / \mathrm{tmi}$. 12339

12. Basta, S., Soekirman, D. Karyadi, and N. Schrimshaw (1979). Iron de_ciency anemia and the productivity of adult males in Indonesia. American Journal of Clinical Nutrition 1979;32,916-925.

13. Thomas, D., E. Frankenberg, J. Friedman, J.-P. Habicht, N. Jones, C. McKelvey, G. Pelto,B. Sikoki, J. Smith, C. Sumantri, and W. Suriastini . Causal effect of health on labor market outcomes: Evidence from a random assignment iron supplementation intervention. 2006 California Center for Population Research Working Paper. Available at. http:// people. virginia. edu/ sns5r/microwkshp/dthomas.pdf. Accessed on $10^{\text {th }}$ Apri 2015

14. Rush D. Nutrition and maternal mortality in the developing world. Am J Clin Nutr. 2000 Jul;72(1 Suppl): 212S-240S.

15. Grantham-McGregor S, Ani C. A review of studies on the effect of iron deficiency on cognitive development in children. J Nutr. 2001 Feb;131(2S-2): 649S666S; discussion 666S-668S.
16. Walter, T., I. D. Andraca, P. Chadud, and C. Perales. Iron deficiency anemia: Adverse effects on infant psychomotor development. Pediatrics.1989 84 (1), 7-17

17. Scrimshaw, N. Infection and Nutrition: Synergistic Interactions, 2000 Chapter VI.3. Cambridge University Press.

18. Vijayaraghavan K. Control of micronutrient deficiencies in India: obstacles and strategies. Nutr Rev. 2002 May;60(5 Pt 2):S73-6.

19. WHO/ CDC. Best indicators to assess iron deficiency, a major cause of anemia. 7th May 2004. Available at http://www.who.int/. Accessed on 5 January 2015

20. Mehta BC. Irondeficiencyamongstnursing students. Indian J Med Sci. 2004 Sep;58(9):389-93.

21. UNICEF/UNU/WHO. Iron deficiency anemia: assessment, prevention, and control. A guide for programmemanagers.WHO/NHD,2001.Availableathttp ://www.who. int/nutrition/ publications/ micronutrients/ anaemia_ iron_deficiency/ WHO_NHD_01.3/en/. Accessed on $20^{\text {th }}$ February 2015.

22. Internationalcommittee for standardization in haematology.Recommendations for haemoglobinometry in human blood. Br J Haematol. 1967 Apr;13:71-5. doi:10.1111/j.1365-2141.1967.tb00751.x

23. Siedel J, Wahlefeld AW, Ziegenhorn J. A new iron ferrozine reagent without deproteinization. Clin Chem. 1984; 30:975.

24. Siegal S, Castellan Jr NJ. Non-parametric Statistics for the behavioral sciences, New York: McGraw-Hill Inc; 1988: 190-216.

25. SPSS Inc. The SPSS guide to data analysis. SPSS, Inc., Chicago .

26. Leard statistics. Binominal logistic regression using SSPS statistics. Statistical tutorials and software guides. 2015. Available at https://statistics.laerd. com. Accessed on 15 January 2017

27. Saha J, Sarkar D. Prevalence of iron deficiency and iron deficiency anemia among nursing students of Bilaspur Chhattisgarh. Int J Med Res Rev. 2015;3 (7): 738-42. doi: 10.17511/ijmrr.2015.i7.139. 


\section{Original Research Article}

28. Spears, D. and J. Hammer . Village sanitation externalities and children's human capital: Evidence from a randomized experiment by the Maharashtra government. Technical report, RICE working paper. 2012. Available at.www. riceinstitute. org. Accessed on 15 January 2015.

29. Curtis V, Cairncross S. "Effect of washing hands with soap on diarrhea risk in the community: a systematic review". Lancet Infectious Diseases. 2003; 3 (5): 275-81..doi:10.1016/S1473-3099(03)00606-6

30. Jenkins, M. and V. Curtis .Achieving the 'good life': Why some people in rural Benin want latrines. Social Science and Medicine. 2005; 61(11): 2446-2459. doi:10. 1016/j. socscimed.2005.04.036

\section{How to cite this article?}

Saha J, Mazumder S. (Sen), Samanta A. Impact study of hygiene and health counseling as a controlling measure of iron deficiency Anemia. Int J Med Res Rev 2018;6(01):33-42. doi:10.17511/ijmrr. 2018.i01.06. 